Beside the information supplied by nitrogen metabolism, blood urea is the most frequently cited in the literature. Thus, plasma urea level (PUL) varies with dietary nitrogen content (BAS et al., 1980 ; GIGER \& SAUVANT, 1985). In latin square experiments with dairy goats, we showed that PUL varied widely with feeding frequency or starvation and with time of sampling. These variations reduce the significance of PUL for the estimation of nutritional status in dairy goats.

Milk urea level (MUL) was strongly correlated with PUL $(r=0.91, n=189)$. MUL could be considered as a good estimator of PUL daily mean. TUL was correlated with : 1) the difference between dietary PDIN and PDIE values ; 2) the excess of digestible nitrogen intake over digestible nitrogen requirements.

Using 169 nitrogen balances in lactating goats, we showed that urinary allantoin (U. All) was strongly correlated with digestible organic matter and fermentescible nitrogen $(r=0.67)$. U. All could be used as an indicator of rumen microbial activity but several physiological factors which might interfere should be taken into account.

Mean blood allantoïn level in dairy goats was $35.7 \mathrm{mg} / 1(\sigma=6.3, \mathrm{n}=58)$. We did not find any correlation between U. All and blood allantoïn level.

Orotic acid content of milk measured for the first five months of lactation $(9.1 \mathrm{mg} / 1$; $\sigma=2.3 \mathrm{mg} / \mathrm{l}, \mathrm{n}=159$ ) varied especially during the first month but did not change after this period. For that reason, milk orotic acid was a poor indicator of nitrogen metabolism.

In conclusion, the simultaneous utilization of milk urea level and urinary allantoïn excretion might improve our knowledge of the nitrogen nutritional status in dairy goats.

Key words : Dairy goats, urea, allantoïn, nitrogen.

\title{
Preliminary studies on nitrogen nutrition of lactating Damascus goats
}

\author{
M. HADJIPANAYIOTOU \\ Agricultural Research Institute, Nicosia, Cyprus
}

Three trials were conducted to study the effect of $\mathrm{N}$-intake on the performance of lactating goats. The concentrate mixtures used in these studies were composed of barley grain, a $\mathrm{N}$-supplement source (soybean meal, urea or fish meal) wheat bran and a macro/micro element vitamin mixture. The mixtures were fed along with barley straw $(0.2 \mathrm{~kg} / \mathrm{head} / \mathrm{day})$ and barley hay $(0.5 \mathrm{~kg} / \mathrm{head} / \mathrm{day})$ to meet maintenance and milk production energy requirements. Dietary $\mathrm{N}$ concentration in the concentrate mixture was adjusted by altering the proportion of the $\mathrm{N}$-supplement. Dietary $\mathrm{N}$-concentration did not affect total feed intake in any of the 3 trials.

In trial 1, 49 goats were randomly assigned to 2 diets (10 or 14 p. $100 \mathrm{CP}$ ) on the 3rd day post kidding. The trial lasted until weaning of kids ( $55 \pm 2$ days). Increasing CP-intake through higher levels of soybean meal, improved milk yield (MY) $(2.95$ v $2.49 \mathrm{~kg} /$ day) and milk CP-content $(40 \mathrm{v} 36 \mathrm{~g} / \mathrm{kg}$ ). Type of suckling (single $\mathrm{v}$ twin) affected MY (single $2.25 \mathrm{v}$ twin $3.21 \mathrm{~kg} /$ day). CP-intake of goats did not affect growth rate of kids.

In trial 2, 12 goats ( 75 days in milk) were allocated to 4 groups. Within each group, goats randomly received one of $4 \mathrm{~N}$-supplements : soybean meal (S), fish meal (F), S plus urea (SU) or FU. For each group, a $3 \times 3$ Latin square with three 22 day periods and 3 levels : 80,120 or $160 \mathrm{~g} \mathrm{CP} / \mathrm{kg}$ DM was used. Increasing CP-intake resulted in higher MY in the FU group only. Differences in MY among N-supplements were not significant ( $\mathrm{S} 1.79$; SU $1.88 ; \mathrm{F} 1.89 ; \mathrm{FU} 1.91 \mathrm{~kg} /$ goat). In all groups, higher $\mathrm{CP}$-intake did not alter milk composition or $\mathrm{OM}$ digestibility but increased $\mathrm{CP}$ digestibility ; urinary-N output, $\mathrm{N}$-absorbed 
and retained were higher in the high compared with the low $C P$ diets. Using the $\mathrm{N}$-balance data obtained in this trial the $C P$ requirements of a $60 \mathrm{~kg}$ goat, producing $1 \mathrm{~kg}$ milk of 4 p. 100 protein and maintaining $\mathrm{N}$-equilibrium was estimated to $129 \mathrm{~g}$.

In trial 3, 45 goats ( 90 to 120 days in milk) were divided into 5 groups. The 5 groups were allocated to 5 treatments : one with no $\mathrm{N}$-supplement $(8 \mathrm{p} .100 \mathrm{CP})$ and another $2 \mathrm{CP}$ levels (12 or 16 p. 100) supplied either by $S$ or SU. Increasing CP-intake did not alter MY or milk composition.

It is concluded that the lower level $(10 \mathrm{p}$. 100) of CP used during the postweaning period did not affect MY, whereas CP levels higher than 10 p. 100 are required during the preweaning period.

Key words : Damascus goat, nitrogen intake, milk yield.

\title{
Effects of types of concentrates on digestibility and nitrogen utilization of a forage based diet in lactating goats
}

\author{
R. DACCORD \\ Swiss Federal Research Station for Animal Production \\ Grangeneuve, CH-1725 Posieux
}

\begin{abstract}
During a balance trial, 15 lactating goats were assigned to three dietary treatments based on hay and concentrate, supplemented on a net energy basis with $25 \mathrm{p}$. 100 cereals (diet A), 25 p. 100 fodder beet (diet B) or 25 p. 100 animal fat (diet C). In a first experimental period, hay made up $30 \mathrm{p} .100$, in the second one $60 \mathrm{p} .100$ of the calculated net energy intake.
\end{abstract}

In both periods, goats ingested more hay with the cereals and fat supplements than with the beet supplement $\left(\mathrm{kg} \mathrm{DM} /\right.$ day, 1st period : $\mathrm{A}=1.058^{\mathrm{a}} ; \mathrm{B}=0.820^{\mathrm{a}} ; \mathrm{C}=0.910^{\mathrm{a}}$; 2nd period : $\left.\mathrm{A}=1.557^{\mathrm{ab}} ; \mathrm{B}=1.354^{\mathrm{a}} ; \mathrm{C}=1.790^{\mathrm{b}} ; \mathrm{P}<0.5\right)$. The energy intake of the animals on the fat diet was larger only at the lower concentrate level. The beet and fat supplements increased the digestibility of organic matter (1st period : $\mathrm{A}=72.8^{\mathrm{a}} ; \mathrm{B}=78.2^{\mathrm{b}}$; $\mathrm{C}=75.9^{\mathrm{ab}} ;$ 2nd period : $\mathrm{A}=71.1^{\mathrm{ac}} ; \mathrm{B}=75.7^{\mathrm{b}} ; \mathrm{C}=73.3^{\mathrm{c}} ; \mathrm{P}<0.5$ ), nitrogen (1st period : $\mathrm{A}=60.7^{\mathrm{a}} ; \mathrm{B}=64.6^{\mathrm{b}} ; \mathrm{C}=73.8^{\mathrm{c}} ;$ 2nd period : $\mathrm{A}=60.8^{\mathrm{a}} ; \mathrm{B}=67.7^{\mathrm{b}} ; \mathrm{C}=74.7^{\mathrm{c}}$; $\mathrm{P}<0.5$ ) and crude fibre (1st period : $\mathrm{A}=55.3^{\mathrm{a}} ; \mathrm{B}=62.5^{\mathrm{b}} ; \mathrm{C}=58.5^{\mathrm{ab}} ;$ 2nd period : $\left.\mathrm{A}=61.8^{\mathrm{a}} ; \mathrm{B}=65.0^{\mathrm{ab}} ; \mathrm{C}=67.9^{\mathrm{b}} ; \mathrm{P}<0.5\right)$ at both levels of concentrates. These supplements decreased the proportion of faecal $\mathrm{N}(\mathrm{g} \mathrm{N} / 100 \mathrm{~g} \mathrm{~N}$ intake, 1st period : $\mathrm{A}=39.4^{\mathrm{a}} ; \mathrm{B}=35.4^{\mathrm{b}} ; \mathrm{C}=26.2^{\mathrm{c}} ;$ 2nd period $: \mathrm{A}=39.2^{\mathrm{a}} ; \mathrm{B}=32.3^{\mathrm{b}} ; \mathrm{C}=25.3^{\mathrm{c}} ;$ $\mathrm{P}<0.5)$ and increased the proportion of urinary (1st period : $A=23.7^{\mathrm{a}} ; \mathrm{B}=26.2^{\mathrm{a}}$; $\mathrm{C}=36.0^{\mathrm{b}} ;$ 2nd period : $\left.\mathrm{A}=24.8^{\mathrm{a}} ; \mathrm{B}=32.3^{\mathrm{b}} ; \mathrm{C}=38.9^{\mathrm{c}} ; \mathrm{P}<0.5\right)$. The proportion of $\mathrm{N}$ excreted in milk was about the same with the three diets at the high concentrate level, but was higher with the cereal supplement on the lower concentrate level $\left(A=31.5^{a}\right.$; $\left.\mathrm{B}=27.5^{\mathrm{b}} ; \mathrm{C}=28.0^{\mathrm{ab}} ; \mathrm{P}<0.5\right)$. Both beet and fat supplements increased the proportion of $\mathrm{N}$ retained (not significantly).

In blood, the fat supplement increased the concentration of urea, glucose, triglycerides and GLDH and decreased the concentration of $\beta$-hydroxybutyrate. The beet supplement decreased the concentration of triglycerides and increased the concentration of $\beta$-hydroxybutyrate at both concentrate levels; furthermore it increased the glucose concentration only at the low level.

The fat supplement increased the production of 3.5 p. 100 fat corrected milk, increasing both the concentration the quantity of fat and lactose.

Key words : Goat, milk production, concentrates, digestibility, nitrogen utilization, cereals, fodder beet, animal fat. 